Annals of Plant Sciences

ISSN: 2287-688X

OPEN ACCESS

Research Article

www.annalsofplantsciences.com

\title{
Transformation and confirmation of GUS gene expression in Solanum melongena L. of PLR 1 cultivar
}

Vinod KannaS. ${ }^{*}$ and N. Jayabalan ${ }^{2}$

${ }^{1}$ Department of Botany, School of Science, Tamil Nadu Open University, Saidapet, Chennai, Tamil Nadu, INDIA.

${ }^{2}$ Department of Plant Science, Bharathidasan University, Tiruchirappalli, Tamil Nadu, INDIA.

Received: 3/16/2018; Revised: 3/23/2018; Accepted: 3/26/2018

\begin{abstract}
In the present study GUS gene transformation was carried out in eggplant using Agrobacterium strain with pBAL2 vector harboring gus gene and $n p t I I$ as selection marker gene. The factors which are affecting (enhancing) the frequency of transient gus gene expression are different physical and biochemical variables has been carried out. It is observed that the 4 day precultured explants showed the minimum survival rate in the medium when compared with 2 day co cultivated medium. The explants which had undergone co-cultivation for 4 to 5 days showed GUS activity, the tissues were adversely affected due to the overgrowth of bacteria. The gene specific primers for $n p t I I$ and gus gene were used for amplification and it has given $680 \mathrm{bp}$ and $1.9 \mathrm{~kb}$ amplified fragments respectively and recorded. The band was detected in the selected plants, but it was absent from the negative control (non-transformed) plant in the Southern hybridization. Our experiment showed 0.80-1.60 percentage of efficiency in transformation. With a total of 849 infected shoots were undergone confirmation tests which results 9 PCR positives $(1.06 \%$ efficiency). The Transformant kept in the Environmental Growth Chamber and transferred to field condition subsequently.
\end{abstract}

Keywords: Agrobacterium tumifaciens, MS Salts, infection, pBAL2 and transformant

\section{Introduction}

The transfer of foreign genes into plants has provided new ways to study regulation of development and biosynthetic process. Agrobacterium tumifaciens mediated transformation is preferred because of its simplicity and efficiency in providing stable integration of transferred DNA into the plant genome. Transformation mediated by Agrobacterium tumefaciens, a soil plant pathogenic bacterium, has become the most used method for introduction of foreign genes into plant cells and the subsequent regeneration of transgenic plants. A. tumefaciens naturally infects the wound sites in dicotyledonous plant causing the formation of the crown gall tumors. The first evidences indicating this bacterium as the causative agent of the crown gall goes back to more than ninety years (Smith and Townsend, 1907). Since that moment, for different reasons a large number of researchers has focused on the study of this neoplastic disease and its causative pathogen. During the first and extensive period, scientific effort was devoted to disclose the mechanisms of crown gall tumor induction hoping to understand the mechanisms of oncogenesis in general, and to eventually apply this knowledge to develop drug treatments for cancer disease in animals and humans. When this hypothesis was discarded, the interest in crown gall disease largely decreased until it was evident that this tumor formation may be result of the gene transfer from A. tumefaciens to infected plant cells.

\footnotetext{
${ }^{*}$ Corresponding Author:

Dr. S.Vinod Kanna,

Assistant Professor,

School of Science, Tami Nadu Open University

Chennai - 600015, Tamil Nadu, India.

E-mail: winskan@gmail.com
}

A. tumefaciens has the exceptional ability to transfer a particular DNA segment (T-DNA) of the tumorinducing (Ti) plasmid into the nucleus of infected cells where it is the stabley integrated into the host genome and transcribed, causing crown gall disease (Nester et al., 1984; Binns and Thomashaw, 1988). T-DNA contains two types of genes; the oncogenes, encoding for enzymes involved in the synthesis of auxins and cytokinins and the responsible for tumor formation; and genes encoding for the synthesis of opines. These compounds, produced by condensation between aminoacids and sugars, are synthesized and excreted by the crown gall cells and consumed by $A$. tumefaciens as carbon and nitrogen sources. The initial results of the studies on t-DNA transfer process to plant cells demonstrate three important facts for the practical use of this process in plants transformation. Firstly, the tumor formation is a transformation process of plant cells resulted from transfer and integration of T-DNA and the subsequent expression of T-DNA genes.

Secondly the T-DNA genes are transcribed only in plant cells and do not play any role during the transfer process. Thirdly, any foreign DNA placed between T-DNA borders can be transferred into plant cell, no matter where it comes from. These well-established facts, allowed the construction of the first vector and bacterial strain systems for plant transformation (Hooykaas and Schilperoort, 1992; 
Deblaere et al., 1985; Hamilton, 1997; Torisky et al., 1997.)

\section{Materials and Methods}

Pre-culture of explants

Eggplant cultivar of PLR1 was in vitro germinated on half strength MS medium. After germination, nodal region was removed from germinated seedlings and the nodal regions were used as explants source. Before going into the infection treatment of Agrobacterium on explants, it is essential to treat the explants on the medium which should employed in infection medium. To make the tissues competent and withstand the bacterial infection, this step must be essential. Explants were excised from 4-8-week-old unaffected plantlets and precultured on growth medium containing MS salts, $1.5 \%$ Glucose, and appropriate PGRs and aminoacids.In present study we used kanamycin as a selection marker with the multiple shoot induction medium. The culture has been tested a wide range from $25 \mathrm{mg} / \mathrm{L}$ to $150 \mathrm{mg} / \mathrm{L}$ of Kanamycin (HiMedia) in the culture medium and then the lethal dose has been identified for the plant cultures. The concentration, in which shoots has been successfully raised has taken as the ideal concentration for further experiments.

Infection of Agrobacterium into target tissues Agrobacterium strain LBA4404 harboring the binary plasmid pBAL2 (18.8kb) was used as vector system for transformation. This system has uid $A /$ gus gene for $\beta$ Glucorouridase enzyme and driven by $35 \mathrm{~S}$ CaMV promoter and terminator sequence act as reportor gene. In that construct a selectable marker gene neomycin phosphortransferase II (nptII) gene driven by nopaline synthase (Nos) promoter and terminator sequences were used. The MS medium was prepared in above said concentration that is $1 / 2$ MS basal medium, $3 \%$ sucrose $100 \mu$ of acetosyringone, and appropriate plant growth regulators and the $\mathrm{pH}$ was adjusted to 5.6-5.8. The bacterial cell density was adjusted to $\mathrm{OD}_{600}$ of 0.8 $1.0\left(5 \times 10^{8}\right.$ cells $\left./ \mathrm{ml}\right)$. Transfered $5 \mathrm{ml}$ of culture to a sterile petri dish, then wound made on explants using sterile blade and transfer the explants to Agrobacterium culture using a spatula, and then left for 2 minute as infection period and blot dry on Whatmann No.1 filter paper, upto this the infection process will be over.

\section{Co-cultivation of infected explants}

After the infection of explants by Agrobacterium the infected explants was transferred to MS medium for shoot induction. This setup was incubated for two days for co-cultivation of culture. This incubation period was for the integration of plasmid to chromosomal DNA. The co-cultivation period was assessed on 12, 24, 36, 48 and 60 hours. The coculture medium was solidified with $0.8 \%$ agar of MS medium and this setup kept to $16 \mathrm{~h} \mathrm{~L} / \mathrm{D}$ photoperiod with low light intensity (1000 Lux).

\section{Selection and regeneration of transformants}

The overgrowth of Agrobacterium may utilize all the nutrients provided to explants in the culture tube, so it is essential to bleach excess growth during the co-cultivation period. Before the transfer of explant culture to the selection medium, the explants were washed with cefataxime at a wide range of concentrations from $50 \mathrm{mg} / \mathrm{L}$ to $200 \mathrm{mg} / \mathrm{L}$ concentration. After giving 2-3 washes with $1 / 2$ strength MS liquid medium, the cultures were transferred to selection medium. Then the explants were subsequently placed on shoot induction medium with $50 \mathrm{mg} / \mathrm{L}$ kanamycin and the culture maintained on $16 / 8 \mathrm{~L} / \mathrm{D}$ photoperiod with low light intensity $(1000 \mathrm{Lux}) 25 \pm 2{ }^{\circ} \mathrm{C}$. The explants were subcultured on the fresh medium at 10 days intervals with same combination. The developed shoots were excised from the explants and transferred to elongation and rooting medium subsequently. The percentage shoot regeneration and average number of shoots per explants were quantified after four weeks of culture. The putative transformed shoots obtained from regenerated plantlets transferred to rooting medium. The escapes (Non-transformed) removed by subculturing the green shoots on respective selection media at a regular interval. The rooted plantlets were hardened in a pot containing garden soil and vermiculite at the ratio of 2:1 at kept at controlled environmental growth chamber (Sanyo, Japan).

\section{Confirmation of putative transformants}

The gus histochemical assay was carried out according to Jafferson (1987) with minor changes. Leaves and some tissues are excised from the putative transformants and it was washed in $50 \mathrm{mM}$ Phosphate buffer (pH7.0). The explants was placed in phosphate buffer containing 1\% Triton X-100 and incubated for 1 hour in a $37^{\circ} \mathrm{C}$ incubator. After one hour the explants were transferred to X-Glu containing solution $(1 \mathrm{mM})$ and placed in a dessicator for vacuum filtration about $5 \mathrm{~min}$. The explants were incubated for about $16-24 \mathrm{hrs}$ at $37^{\circ} \mathrm{C}$. The excess stain was bleached by $95 \% \quad(\mathrm{v} / \mathrm{v})$ ethanol. Explants were removed from X-Gluc solution and washed twice with $\mathrm{ddH}_{2} \mathrm{O}$ and washed once with $70 \%$ ethanol then finally transferred to acetone methanol (1:3) mixture.

The genomic DNA was isolated from young leaves of putative transformants and negative control (untransformed) plants by CTAB method (Doyle and Doyle, 1990). The leaf tissues for about 1.0gm taken and ground well in pestle and mortar using liquid nitrogen and made into powder. The powdered leaf tissues were homogenized and the homogenate was centrifuged for 15-20 minutes. The pellet was collected and re-dissolved in 
extraction buffer. The nucleic acids was lysed by addition of $4 \mathrm{ml}$ of nucleus lysis buffer $(200 \mathrm{mM}$ Trisaminomethane $55 \mathrm{mM}$ CTAB, $\mathrm{pH} 7.5), 1.6 \mathrm{ml}$ of SDS and incubated at $65^{\circ} \mathrm{C}$ for 20 minutes. The mixture was then extracted with mixed solvent of Chloroform / Iso amyl alcohol with 24:1 ratio and equal volume of isopropanol was added (for preciptation). The extracted DNA was estimated by Fluorometric method (Cesarone et al., 1979).

The confirmation of putative transformants was initially starts with polymerase chain reaction. PCR analysis was done as per the procedure of Edwards et al. (1991). The chromosomal DNA was isolated from the transgenic plants were used for amplification of transferred gene, untransferred, positive control and negative controls.

For the amplification of widA gene a pair of primers was employed

(F) 5'- T'TT AAC TAT GCC GGG ATC CAT CGC-3'

(R) 5'- CCA GTC GAG CAT CTC TTC AGC GT-3'

For $n p t I I$ gene

(F) 5'- AAT CTC GTG ATG GCA GGT TGA-3'

(R) 5'- GAG GCT ATT CGG GAT ATG ACT-3'

To check the presence of uidA and $n p t \mathrm{II}$ genes by amplification using PCR for about $1.9 \mathrm{~kb}$ and 680 bp respectively has been done. The PCR reaction to amplify vidA gene and $n p t I \mathrm{I}$ genes, initially took DNA molecule for about 10 ng was more than enough for reaction. The PCR mixture was made upto $25 \mu \mathrm{l}$ with $7.16 \mu \mathrm{l}$ master mix $10 \mu \mathrm{l}$ of DNA with $2.5 \mathrm{mM}$ of dNTPs and 100ng of each primer DNA and Taq polymerase. This PCR reaction was carried out by thermal cycler (Eppendorf, Germany). The reaction was performed for 35 cycles with $94^{\circ} \mathrm{C}$ as preheating and $1 \mathrm{~min}$. for denaturation at $94^{\circ} \mathrm{C}$ and annealing temperature was at $58^{\circ} \mathrm{C}$ maintained and elongation at $72{ }^{\circ} \mathrm{C}$ for uid A gene about $10 \mathrm{~min}$. was proceeded. In the case of nptII gene annealing temperature was shifted to $55^{\circ} \mathrm{C}$. The final PCR product after 35 cylces were analysed by $1 \%$ agarose gel electrophoresis. Agarose gel was prepared at $1 \%$ concentration with $10 \mathrm{X}$ TBE buffer and boiled at $90^{\circ} \mathrm{C}$ with $\mathrm{EtBr}$ then solidified and the gel was casted with creating $100 \mu \mathrm{l}$ capacity well. The sample DNA was prepared using loading buffer at 4:1 ratio and loaded into the well. Electrophoresis was performed at $4-8 \mathrm{v} / \mathrm{cm}$ in $1 \mathrm{X}$ TBE running buffer. After finishing the electrophoresis the gel was observed under Transilluminator or Gel Documentation.

Electroelution of DNA sample was carryout by Maniatis et al. (1982) manual protocols. After the separation of DNA viewed and documentation the bands was fractioned from the gel. The band was excised from the gel and placed inside an activated dialysis tubing containing $200-300 \mu$ l of $0.5 \mathrm{X}$ TBE and the ends of dialysis tubing was closed by a clamp. Then the DNA in the agarose gel piece was allowed to ran out of the piece by electrophoresis in 0.5X TBE buffer for about 1 hour. The DNA was completely eluted and attached to the dialysis bag and it was confirmed by observing under UV light. The current was reversed and run for 20 seconds and visualized under long UV. The DNA attached to the dialysis membrane came into the buffer and the solution was completely collected and measured $1 / 10^{\text {th }}$ volume of $3 \mathrm{M}$ Sodium acetate $(\mathrm{pH} 5.4)$ added and 2.5 volume of $95 \%$ ethanol mixed well and kept at $-20^{\circ} \mathrm{C}$ overnight. The sample was centrifuged for $10 \mathrm{~min}$ at $4^{\circ} \mathrm{C}$ about $12,000 \mathrm{rpm}$ after that $500 \mu \mathrm{l}$ of $70 \%$ ethanol was added in the pellet then another spin for 5 min carried out the final pellet was dried and dissolved in $20 \mu$ l of $0.1 \mathrm{X}$ TE buffer ( $\mathrm{pH}$ 8.0).

The DNA samples were digested by restriction endonucleases, was extracted once with neutral phenol/ Chloroform and twice with water saturated ether and precipitated with ethanol, and later was used for ligation. A concentrated ratio of 1:3 of vector designed to be inserted was maintained for cloning experiments. Approximately 50ng of the vector DNA was used for ligation. Ligation reactions were carried out for $10-12$ hours at ${ }^{`} 14^{\circ} \mathrm{C}$ in the presence of $1 \mathrm{mM}$ ATP and the buffer provided by the manufacturer.

Southern blotting is first devised by E.M. Southern (1975), Southern blotting results in transfer of DNA molecules, usually restriction fragments, from an electrophoresis gen to a nitrocellulose or nylon sheet (referred to as membrane), in such a way that the DNA binding pattern present in gel is reproduced on the membrane. Initially the DNA has to be denatured in the gel. The gel was soaked in $250 \mathrm{ml}$ of denaturation solution in a glassy tray and gently shaken it for $45 \mathrm{~min}$ on a rocker platform at room temperature. The gel was rinsed four times with sterile distilled water (about $250 \mathrm{ml}$ ). Then the gel was neutralized in neutralization buffer and gentle shaken for about $45 \mathrm{~min}$ on a rocker platform. The platform which is used for casting the gel was kept upside down in a glass try containing $200 \mathrm{ml}$ of $20 \mathrm{X}$ SSC. A nylon membrane cut to the size of the gel, wetted distilled water and soaked in 20X SSC was placed over the membrane followed by a dry sheet. Cut crude filter paper to the gel size and stack them on the top to about 8$10 \mathrm{~cm}$ height and kept the glass plate and little weight. After 10-12 hours the membrane was removed and rinsed with 2X SSC and air dried in Whatmann No.1 filter paper and bake at $80^{\circ} \mathrm{C}$ for 30 min and UV crosslinking.

The membrane was kept inside the hybridization bottle by using sterile forceps and pre-warmed $\left(65^{\circ} \mathrm{C}\right)$ hybridization solution $\left(20 \mathrm{ml} / 100 \mathrm{~cm}^{2}\right)$ at the bottom of the bottle. Slowly the membrane was wetted by rotation the bottle without any air bubble. 
Kept the membrane at $65^{\circ} \mathrm{C}$ for 1 hour in a hybridization oven for incubation.

Hybridization analysis is based on the principle that two polynucleotides will form a stable hybrid by base-pairing if their nucleotide sequences are wholly or partly complementary. A specific restriction fragment in a southern blot can therefore be detected if the membrane is probed with second, labeled DNA molecule that has same, or similar, sequence as the fragment being sought. This is the second stage which is carried out in high salt buffer containing detergent, usually $2 \mathrm{X}$ SSC, $1 \%$ SDS. The membrane was placed inside the hybridization bottle and $10 \mathrm{ml}$ of pre-hybridization solution (contains 7\% SDS for blocking) was added. The air bubble was removed carefully. The probe was denatured in boiling water both for $5 \mathrm{~min}$ and chilled on ice immediately. The denatured probe DNA was added to the bottle and hybridization was performed at $65^{\circ} \mathrm{C}$ for $12-24$ hours.

The hybridization solution and rinse the membrane briefly with $20 \mathrm{ml}$ of pre-warmed $\left(65^{\circ} \mathrm{C}\right) 2 \mathrm{X}$ SSC $/ 0.1 \%$ SDS solution. Three subsequent washed were with $20 \mathrm{ml}$ of solutions $2 \mathrm{X}$ SSC $/ 0.1 \%$ SDS at $65^{\circ} \mathrm{C}$ for $30 \mathrm{~min}, 0.5 \mathrm{X}$ SSC $/ 0.5 \%$ SDS for $30 \mathrm{~min}$ and $0.1 \mathrm{X} \mathrm{SSC} / 0.1 \% \mathrm{SDS}$ for $30 \mathrm{~min}$. The washing were done either at low stringency conditions (for heterogenous probes) or at high stringency conditions (for homologous).

\section{Results and Discussions}

Successful eggplant genetic transformation was achieved as early as 1988 (Guri and Sink, 1988) using Agrobacterium-mediated genetic transformation with the co-integrate vector- pMON 200 harbouring $n p t I I$ gene. More recently, an efficient transformation protocol was developed and used for the generation of transgenic eggplants tolerant to abiotic stresses by the introduction of bacterial mtlD gene (Prabhavati et al., 2002).

\section{The Plant Material}

Transformation was carried out in eggplant PLR1 cultivar using Agrobacterium stain with pBAL2 vector harboring gus gene and $n p t \mathrm{II}$ as selection marker gene for the study. The factors which are affecting (enhancing) the frequency of transient gus gene expression are different physical and biochemical variables has been carried out.

The protocols were already optimized by many researchers for various explants in eggplant (Magioli and Mansur, 2005). An optimization of factors that influence transformation efficiency, including length of pre and post-coculture periods, explant type, and genotype was performed using a TDZ-based organogenic system (Magioli et al., 2000). The efficiency of transformation protocols based on organogenesis may be influenced by the antibiotic used to eliminate $A$. tumefaciens. For example, augmentin can cause enhanced shoot proliferation induced by TDZ (Billings et al., 1997). Recently, an organogenic system from root explants was applied in a protocol for transformation of variety MEBH 11. These explants demonstrated a high susceptibility to Agrobacterium and quick regeneration capacity on selection media, resulting in $82.5 \%$ of transgenic calli induction with a means of 24 transgenic shoots per callus (Franklin and Sita 2003). Among these, the protocol optimized in our laboratory was showed the edge over some other protocols interms of quick and enormous proliferating capacity of the meristems. In this study, differential effects of various cytokinins on shoot on shoot proliferation from nodal explants were assessed.

\section{Preculture of explants}

Preculture is an important step involved in Agrobacterium mediated transformation studies. The transformation efficiency can be increased by manipulations are based on increasing the number of competent cells for transformation by preculturing explants (McHughen et al., 1989). In the current study, the explants were taken and sterilized preculured on medium for a series of time duration like 2,4,6,8,10,12 and 14 days of preculture. Among seven experiments six-day preculture was very effective of nearly 60 percentage of response was reached (Table 1). The present study, on preculture also observed that the 4 day precultured explants showed the minimum survival rate in the medium, because the explants were unable to withstand the vigorous reactive power of Agrobacterium. Other then two experiments $\left(4^{\text {th }}\right.$ and $6^{\text {th }}$ day preculture), the survival rate and the percentage of response were low and slow. Since low frequency of regeneration efficiency in the extended precultured explants, 6 day precultured explants were taken for the transformation studies. The results clearly indicated that preculutre period has influenced the frequency of eggplant transformation by using Agrobacterium mediated transformation efficiency as the result of the determination of preculture period can attribute to initiation of active cell division before receive $\mathrm{T}$ DNA gene from the Agrobacterium.

\section{Effect of Antibiotics and selection marker}

The induction rate under different concentration of antibiotics is shown in Table 2. Shoot induction rate without Agrobacterium inoculation was not significantly different among application of antibiotics. The sensitivity of well-developed shoots kanamycin $(0-100 \mathrm{mg} / \mathrm{L})$ was tested. The increasing concentration of kanamycin leads to the bleaching of shoots and $100 \%$ bleaching were observed within a week on $100 \mathrm{mg} / \mathrm{L}$ concentration. As we looked into the results, between $40-60 \mathrm{mg} / \mathrm{L}$ concentration of kanamycin was the ideal concentration for shoot induction and produces 2 to 4 shoots between them 
as a sub lethal dose. On the medium with the kanamycin concentration of $60 \mathrm{mg} / \mathrm{L}$, shoots continued to grow during the third cycle of selection. Thus, kanamycin $60 \mathrm{mg} / \mathrm{L}$, was found optimum, as it was not detrimental to transformed shoots or as slow in its effect as that of the lower concentration, which would lead to the recovery of escapes. To strike a balance between the elimination of untransformed shoots and proliferation of putative transformants, kanamycin at $60 \mathrm{mg} / \mathrm{L}$ was proved to be effective. The control plants failed to survive in the first cylcle of selection on medium with kanamycin 60mg/L (Fig.1).

\section{Effect of Acetosyringone on transformation}

The influence of acetosyringone might be the phenolic inducer and it will be the strain dependent (Agrobacterium). It is known to be the activator of the vir genes of the Ti plasmid that would trigger the successful transfer of t-DNA (Pelayo et al, 2012). In this experiment acetosyringone has been tried for $0-100 \mathrm{mg} / \mathrm{L}$ (Table 3) before to cocultivation in the co-cultivation medium to analyse the effect of acetosyringone in transformation efficiency. In the absence of acetosyringone some of the explants showed the GUS expression. But, the successful (high frequency) expression of GUS observed in the presence of acetosyringone. The ideal concentration for acetosyringone is $60 \mu \mathrm{l} / \mathrm{L}$ $(\mathrm{v} / \mathrm{v})$. The presence of acetosyringone in the inoculation media was crucial for T-DNA delivery and improving transformation rate as reported earlier by Li., et al. (2003) in Capsicum annum. Acetosyringone reportedly activates the transcription of Agrobacterium virulence genes that can greatly increase the transformation rate (Chakravarthy and Pruski., 2010).

\section{Co-cultivation duration}

The duration of the co-cultivation period was extended from 0 days to 7 days. Co-cultivation of nodal explants resulted in high frequency of transformation as revealed by the high survival frequency. But, co-cultivation above 7 days the shoot regeneration was very poor and bacterial overgrowth observed in all stages of selection and failed to be controlled even in the third cycle of selection. The ideal co-cultivation period was 2-7 days period for transformation in many plant species (Sujatha and Shailaja, 2005). In our experimernt, two days co-cultivation period was preferred (Chart). Although prolonging inoculation and co-cultivation time period usually yields more efficient T-DNA delivery, but higher cell-damage and necrosis occurs and leads to the cell death. Hence, in the current experiment two days cocultivation period was preferred (Chart). After 2 days of co-cultivation, leaching of explants was observed and the explants were washed with sterile half strength mMS medium $250 \mathrm{mg} / \mathrm{L}$ cefotaxime to prevent the overgrowth of Agrobacterium in the infected explants. Then these infected explants were placed subsequently in the selection medium. Cefotaxime totally arrested the overgrowth of Agrobacterium which leads to the death of the explants.

The behavior of the cefotaxime will differ depending upon the explants. In the case of Nicotiana leaf disc good responses observed but in cotyledonary node a poor shoot regeneration obtained by Nauerbyet al., (1997). The vir gene activity, however, must be sustained at a high level during the two-day co-cultivation period. The beneficial effect of acetosyringone during cocultvation to increase Agrobacterium mediated transformation frequencies was reported earlier too (Sheikholeslam and Weeks, 1987).

\section{Shoot elongation and plantlet establishment}

The nodal explants produced with multiple shoots with no base callusing on medium supplemented with $1.5 \mathrm{mg} / \mathrm{L} 2 \mathrm{iP}$. Subculture followed by a cocultivation and culture of node on medium with $1.0 \mathrm{mg} / \mathrm{L} \quad B A P$ and $1.5 \mathrm{mg} / \mathrm{L} 2 \mathrm{iP}$ resulted in enormous expansion of the meristematic region with a large number of tiny green coloured protuberances. Transfer of these cultures to selection medium with $1.5 \mathrm{mg} / \mathrm{L} 2 \mathrm{iP}$ and kanamycin $50 \mathrm{mg} / \mathrm{L}$ led to the differentiation of these protuberances into shoot - like structures. During the second and third cycles of selection, nontransformed cultures became necrotic while putative transformants continued shoot proliferation. Transfer of cultures subjected to three cycles of selection to medium with $0.6 \mathrm{GA}_{3}$ facilitated shoot elongation. All the elongated shoots with two or three distinct nodes developed roots on medium supplemented with NAA. The rooted shoots were acclimatized. The protocol collowed for shoot elongation and plantlet establishment was already standardized by Vinod kanna and Jayabalan, 2010 and 2015.

\section{Histochemical $G U S$ assay}

Histochemical GUS assays indicated that transformation had occurred at specific zones, and each spot represented an independent transformation event. GUS activity was observed from the explants co-cultivated for 2 to 3 days. Although explants which had undergone cocultivation for 4 to 5 days showed GUS activity, the tissues were adversely affected due to the overgrowth of bacteria. It is clear from the result that the co-cultivation time with Agrobacterium needed was 2 to 3 days to obtain efficient expression of GUS in eggplant. With an infection time of $10 \mathrm{~min}, 80 \%$ of the explants showed bacterial overgrowth and a time of 5 min was found optimum since it showed no overgrowth in the selection media. Although prolonged co-cultivation periods more than three days have been successfully used for certain plants (Mourgues et al., 1996), 2 to 3 days co-cultivation has been routinely used in 
most reported transformation protocols, since longer co-cultivation periods frequently result in Agrobacterium overgrowth (Cervera et al., 1998 a and b).

The intensity of gus staining was higher in young leaves and shoot primordial (Fig.1). The Agrobacterium strain is another important factor potentially influencing the efficiency of genetic transformation. Generally, the Agrobacterium strains available for different plant species may vary according to the susceptibility of plant species to strains. Based on the gus expression EHA105 was superior and more effective than the other strains used in eggplant transformation (Lakshmisita and Franklin., 2005).

Table 1. Effect of pre-culture on transformation efficiency of nodal explants after co-cultivation.

\begin{tabular}{cccc}
\hline $\begin{array}{c}\text { Pre- } \\
\text { culture } \\
\text { (in days) }\end{array}$ & $\begin{array}{c}\text { Total } \\
\text { number of } \\
\text { explants } \\
\text { used }\end{array}$ & $\begin{array}{c}\text { Number of } \\
\text { explants } \\
\text { responded }\end{array}$ & $\begin{array}{c}\text { Percentage } \\
\text { of response }\end{array}$ \\
\hline 0 & 100 & 48 & 48.5 \\
2 & 100 & 45 & 45.6 \\
4 & 100 & 51 & 51.2 \\
6 & 100 & 60 & 60.5 \\
8 & 100 & 39 & 39.0 \\
10 & 100 & 35 & 35.6 \\
12 & 100 & 39 & 39.2 \\
14 & 100 & 26 & 26.0 \\
\hline
\end{tabular}

Table 2. Effect of antibiotics on nodal explants cultured on mMS medium with plant growth regulators (2iP $2.0 \mathrm{mg} / \mathrm{L}$ and BAP $1.0 \mathrm{mg} / \mathrm{L}$ )

\begin{tabular}{ccc}
\hline $\begin{array}{c}\text { Antibiotic } \\
\text { concentration } \\
\text { (Kanamycin) in } \\
\text { mg/L }\end{array}$ & $\begin{array}{c}\text { Percentage } \\
\text { of response }\end{array}$ & $\begin{array}{c}\text { Mean } \\
\text { number } \\
\text { of shoot }\end{array}$ \\
\hline 0 & 45.5 & 05.4 \\
20 & 21.3 & 04.5 \\
40 & 11.5 & 02.2 \\
60 & 07.6 & 01.0 \\
80 & 03.0 & - \\
100 & - & - \\
\hline
\end{tabular}

Table 3. Effect of acetosyringone on transformation efficiency using LBA4404 strain for GUS expression

\begin{tabular}{cccc}
\hline $\begin{array}{l}\text { Concentration } \\
\text { of AS in } \boldsymbol{\mu l}\end{array}$ & $\begin{array}{l}\text { Number } \\
\text { of } \\
\text { explants } \\
\text { used }\end{array}$ & $\begin{array}{l}\text { Number of } \\
\text { shoot } \\
\text { responded }\end{array}$ & $\begin{array}{l}\text { Percentage } \\
\text { of response }\end{array}$ \\
\hline 0 & 50 & 08 & 16.0 \\
20 & 50 & 12 & 24.0 \\
40 & 50 & 15 & 30.0 \\
60 & 50 & 20 & 40.0 \\
80 & 50 & 11 & 22.0 \\
100 & 50 & 09 & 18.0 \\
\hline
\end{tabular}

Table 4. Preliminary transformation using Agrobacterium tumefaciens strain LBA4404 harboring GUS gene and $n p t \mathrm{II}$ gene in the media supplemented with Kan $40 \mathrm{mg} / \mathrm{L}$ and AS about $60 \mathrm{mg} / \mathrm{L}$

\begin{tabular}{cccccc}
\hline Experiment & No. of Explants & No. of $\mathbf{K}^{\mathbf{R}}$ Shoots & Percentage of response & $\begin{array}{c}\text { No. of shoots with } \\
\text { PCR +ve }\end{array}$ & \begin{tabular}{c} 
Efficiency \\
\hline 1
\end{tabular} \\
\hline 127 & 37 & 38 & 29.1 & 2 & 1 \\
3 & 119 & 40 & 31.9 & 1 & 0.84 \\
4 & 121 & 36 & 33.0 & 1 & 0.82 \\
5 & 117 & 35 & 32.5 & 2 & 0.85 \\
6 & 125 & 31 & 28.0 & 1 & 1.60 \\
7 & 122 & 29 & 25.4 & 1 & 0.80 \\
\hline
\end{tabular}

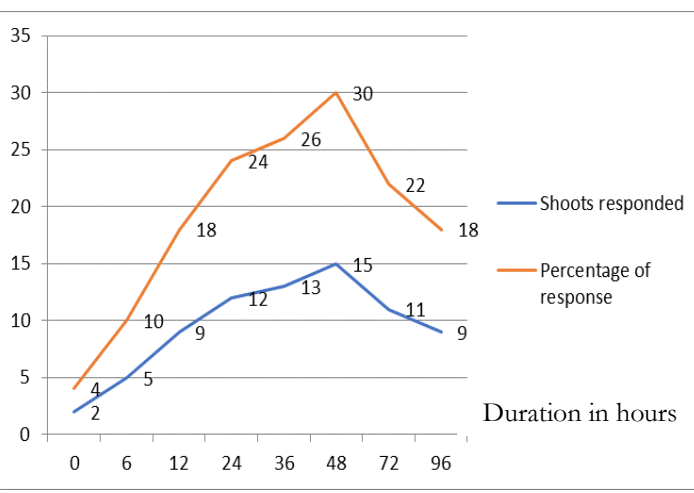

The Chart showing Shoots responded for infection and co-cultivation and percentage shoots responded
Figure 1. GUS expression of Solanum melongenaL.

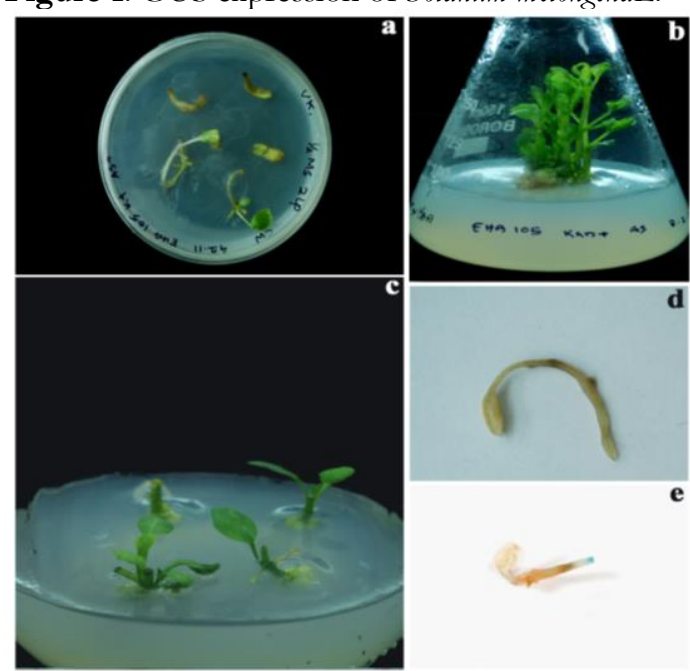

a- Infection; b-Co cultivation; c-Selection;

d-Infected shoot and $e$ - GUS expression 
Figure 2. PCR amplification and southern confirmation of GUS
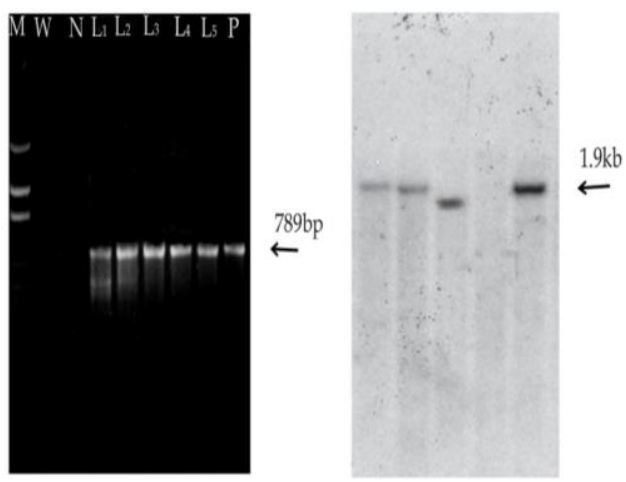

\section{Molecular conformation}

During the regeneration of putative transformants, mMS medium (half strength) was used as the selection medium. Screening was carried out twice, and following that, surviving putative transformed plants were subcultured on fresh hormone-free MS media prior to transfer into soil. In the present study, gene transfer was confirmed by polymerase chain reaction the amplified sequences were resolved in 1\% agarose gel electrophoresis for $n p t \mathrm{II}$ and gus gene in kanamycin resistant putative transformed plants that were obtained after three cycles of binary plasmid pBAL2. The gene specific primers for $n p t I I$ and gus gene were used for amplification and it has given 680bp and $1.9 \mathrm{~kb}$ amplified fragments respectively (Fig.2). The band was detected in the selected plants, but it was absent from the negative control (non-transformed) plants. The transformation frequency of Agrobacterium was evaluated on the basis of PCR positive plant and in relation to the total number of cocultivated explants. The PCR analysis indicated $20 \mathrm{mg} / \mathrm{L}$ was sufficient to eliminate escapes. Three PCR positive transformed plants were selected for southern hybridization analysis. Our experiment showed 0.80-1.60 percentage (Table 4) of efficiency in transformation.

Southern hybridization analysis of genomic DNA from transgenic plants revealed that the nptII gene had integrated into the eggplant genome of different individuals with diverse copy numbers and insertion sites. All samples from transformed plants showed that the $n p t \mathrm{II}$ gene was stably integrated into atleast one site of the plant nuclear genome. The digestion of nuclear DNA from transgenic plants with restriction enzymes HindIII should yield a fragment containing a portion of T-DNA. The HindIII digest of DNA from all of the regenerantsanalysed possessed one or more fragments, all of which were longer than the distance from the HindIII site to right border of pBAL2, which is the portion of the vector DNA carrying the $n p t I I$ gene. Since these fragments represent hybrid molecules containing DNA from both the vector and the plant genome, they demonstrate integration of the transgene and could be used to estimate copy numbers and number of integration sites of the transgene. The number and intensity of the bands indicate that the transgenic eggplants carry the $n p t I \mathrm{I}$ gene at one to two sites of the plant genome (Fig.2). With a total of 849 infected shoots were undergone confirmation tests which results 9 PCR positives (1.06\% efficiency). Random integration of T-DNA fragment to host genome was occurred and this result was well supported by Wallroth et al., 1986, this suggests that in the present experiments, plants selected from the same explants may have originated from the same transformation event. Southern hybridization result showed that the stable integration of foreign DNA in the transgenic plants.

\section{Conclusions}

In conclusion, rapid transformation and regeneration in eggplant can be achieved by manipulating media and culture conditions before and during T-DNA delivery. The stable integration of transgenes in the transformed eggplants by this method was confirmed by PCR and Southern hybridization. This protocol not only reduces the regeneration time but also gives greater number of shoots and stable transformed plants. Due to its high cooking and processing quality, eggplant is commercially a preferred cultivar in many Asian countries, but previous efforts have reported difficulty in regenerating large number of transgenic plants in this cultivar. The development of an efficient transformation protocol for this eggplant cultivar to generate a large number of independent transgenic lines as described here is crucial to carry out further work on functional genomics.

\section{References}

1. Billings $\mathrm{S}$, Jelenkovic $\mathrm{G}$, Chin $\mathrm{CK}$ and Eberhadt J. The effect of growth regulationandantibiotics on eggplant transformation. Journal of American Society of Horticultural Science, 122 (1997): 158-162.

2. Binns $\mathrm{AN}$ and Thomashow MF. Cell biology of Agrobacterium infection andtransformation of plants. Annual Review of Microbiology, 42(1988): 575-606.

3. Cervera M, Juárez J, Navarro A, Pina JA, Durán-Vila N, Navarro Land Peña L. Genetic transformation and regeneration of mature tissues of woody fruitplantsbypassing the juvenile stage. Transgenic Research, 7(1998a):5159.

4. Cervera M, Pina JA, Juárez J, Navarro A, Navarro L, and Peña L. Agrobacterium- mediated transformation of citrange: factors affectingtransformation and regeneration. Plant Cell Reports, 18(1998b): 271-278. 
5. Cesarone CF, Bolongnesi $\mathrm{C}$ and Santi L. Improved microfluorometric DNA determination in biological material using 33258 Hoechst. Annals of Biochemistry, 100(1979):188 - 197.

6. Chakravarty and Pruski. Rapid regeneration of stable transformants in cultures of potato by improving factors influencing Agrobacteriummediated transformation. Advances in Bioscience and Biotechnology, 1(2010):409-416.

7. Deblaere R, Bytebier B, De Greve H, Deboeck F, Schell J, Van Montagu M andLeemans J. Efficient octopineTi plasmid-derived vectors for Agrobacterium- mediated gene transfer to plants. Nucleic Acid Research, 13 (1985): 47774788.

8. Doyle JJ and Doyle JL. Isolation of plant DNA from fresh tissue. Focus (1990), 12: 13-15.

9. Edwards, K., Johnstone, C., and Thompson, C. (1991). A simple and rapid method for thepreparation ofgenomic plant DNA for PCR analysis. Nucleic Acids Research, 19(1990): 1349.

10. Franklin F, Sheeba CJ and Lakshmisita G. Regeneration of Eggplant (Solanummelongena L) from root explant. In Vitro Cellular and Developmental Biology - Plant, 40.2 (2004):188191.

11. Guri A and Sink KC. Agrobacterium Transformation of Eggplant 1. Journal of Plant Physiology, 133.1 (1988): 52-55.

12. Guri A and Sink KC. Interspecific somatic hybrid plants between eggplant (Solanum melongena) and Solanum torvum. Theoretical and Applied Genetics, 76.4 (1988): 490-496.

13. Hamilton CM. A binary-BAC system for plant transformation with high-molecularweight DNA. Gene, 200(1997):107-116.

14. Hooykaas PJJ and Shilperoort RA. Agrobacterium and plant genetic engineering. Plant Molecular Biology, 19(1992):15-38.

15. Jefferson RA. Assaying chimeric genes in plants: The GUS gene fusion system. Plant Molecular Biology Report, 5(1987):387-405.

16. Li D, Zhao K, Xie B, Zhang B and Luok. Establishment of highly efficient transformation system for pepper (Capsicum annum L.). Plant Cell Reports, 21(2003): $\quad 785-$ 788.

17. Magioli C, Rocha APM, Oliveira DE and Mansur E. Efficient shootorganogenesisofeggplant melongena L.) induced by thidiazuron. Plant Cell Reports, 17(1998): 661-663.

18. Magioli C, Rocha APM, Tarré E, SantiagoFernandes LD, Oliveira DE, Krul WR andMansurE. Effect of morphological factors, antibiotics and Agrobacteriumco-cultivation in theefficiency of somatic embryogenesis of eggplant (SolanummelongenaL.). Journal of Plant Biotechnology, 3.1 (2001): 19-25.

19. Maniatis T, Fritsch EF and Sambrook J. Molecular Cloning. A Laboratory Manual, published by Cold Spring Harbor Laboratory Press, NY (1982).

20. McHughen A, Jordan M and Fiest G. A preculture period prior to Agrobacteriuminoculatedincrease production to transgenic plants. Journal of Plant Physiology, 135(1989):245-248.

21. Mourgues F, Chevreau E, Lambert $\mathrm{C}$ and de Bondt A. Efficient Agrobacterium mediated transformation and recovery of transgenic plants from pear (Pyruscommunis L.). Plant Cell Reports, 16 (1996):245-249.

22. Nauerby $B$, Billing $K$ and Wyndaele $R$. Influence of the antibiotic timentin on plantregeneration compared to car benicillin and cefotaxime in concentrations suitable forelimination of Agrobacterium tumefaciens. Plant Science, 123(1997): 169-177.

23. Nester EW, Gordon MP, Amasino RM, and Yanofsky MF. Crown gall: A molecular and physiological analysis. Annual Review of Plant Physiology, 35(1984): 387-413.

24. Pelayo Pérez-Piñeiro1, Jorge Gago1, Mariana Landín and Pedro P. Gallego. AgrobacteriumMediated Transformation of Wheat: General Overview and New Approaches to Model and Identify the Key Factors Involved. Transgenic Plants - Advances and Limitations. INTECH, UK. 2012.

25. Prabhavathi V, Yadav JS, Kumar PA and Rajam MV. Abiotic stress tolerance intransgenic eggplant (Solanum melongena L.) by introduction of bacterial mannitolphosphodehydrogenase gene. Molecular Breeding, 9.2 (2002): 137-147.

26. Sheikholeslam SN and Weeks DP. Acetosyringone promotes high efficiencytransformation of Arabidopsis thaliana explants by Agrobacterium tumefaciens. Plant Molecular Biology, 8.4 (1987):291-298. 
27. Smith EF and Townsend CO. A plant tumour of bacterial origin. Science, 25(1907): 671-673.

28. Southern EM. Detection of specific sequences among DNA fragments separated by gel electrophoresis. Journal of Molecular Biology, 98(1975): 503-517.

29. Sujatha M and Sailaja M. Stable genetic transformation of castor (Ricinus communisL.) via Agrobacterium tumefaciens-mediated gene transfer using embryo axesfrommatureseeds. Plant Cell Reports, 23(2005):803-810.

30. Torisky RS, Kovacs L, Avdiushko S, Newman JD, Hunt AG and Collins GB. Development of a binary vector system for plant transformation based on supervirulent Agrobacterium tumefaciens strain Chry5. Plant Cell Reports, 17(1997):102108.

31. Vinod Kanna S and Jayabalan N. Influence of N6-(2-isopentenyl) adenine on in vitro shoot proliferation in Solanum melongena L. International Journal of Academic Research. 2(2010): 98-100.

32. Vinod kanna S and N. Jayabalan. Regeneration via Direct Organogenesis from Leaf Segments of Eggplant (Solanum melongena L.). Journal of Plant Sciences, 10.3 (2015): 90-98.

33. Wallroth M, Gerats AGM, Rogers SG, Fraley RT and Horsch RB. Chromosolmal Localization in Petunia bybrid. Molecular Genetics and Genomics, 202(1986): 6- 15.

34. Zupan JR, and Zambryski PC. Transfer of TDNA from Agrobacterium to the plantcell. Plant Physiology, 107(1995):1041.1047.

\section{Cite this article as:}

Vinod KannaS. and N. Jayabalan. Transformation and Confirmation of GUS gene Expression in Solanum melongena L. of PLR 1 Cultivar. Annals of Plant Sciences 7.4 (2018) pp. 2185-2193.

do $\mathrm{http}: / / \mathrm{dx}$. doi.org/10.21746/aps.2018.7.4.19

Source of support: Department of Botany, DDU Gorakhpur University

\section{Conflict of interest: Nil}

